\title{
AKTIVITAS ENZIM BROMELIN DARI EKSTRAK KULIT NENAS (Anenas comosus)
}

\author{
Maureen Kumaunang ${ }^{1)}$, Vanda Kamu ${ }^{1)}$ \\ ${ }^{1)}$ Program Studi Kimia FMIPA Universitas Sam Ratulangi, Manado \\ maureen273@yahoo.com
}

\begin{abstract}
ABSTRAK
Limbah dalam jumlah yang cukup banyak selalu dihasilkan dalam industri pengolahan buah nenas. Umumnya limbah nenas yang berupa batang, daun, kulit, dan bonggol belum dimanfaatkan secara optimal. Padahal telah diketahui bahwa daging, batang, dan bonggol nenas mengandung enzim bromelin. Bromelin tergolong kelompok enzim protease sulfhidril yang mampu menguraikan struktur molekul protein menjadi asam-asam amino. Penelitian ini bertujuan untuk mengisolasi enzim bromelin serta menentukan kadar protein dan aktivitas enzim bromelin pada kulit nenas dengan substrat gelatin. Tahap penelitian meliputi penentuan kadar enzim bromelin dan penentuan aktivitas enzim bromelin pada kondisi optimumnya. Hasil isolasi enzim bromelin menunjukkan kadar protein tertinggi pada pengendapan dengan amonium sulfat $60 \%$, yaitu sebesar $0,039 \%$ (b/b). Temperatur optimum enzim bromelin adalah $65^{\circ} \mathrm{C}$ dengan aktivitas sebesar 0,071 unit/menit. pH optimum yang diperoleh adalah 6,5 dengan aktivitas sebesar 0,0101 unit/menit.
\end{abstract}

Kata kunci: bromelin, gelatin, kulit nenas, pengendapan amonium sulfat,

\section{THE ACTIVITY OF BROMELAIN ENZYME ISOLATED FROM PINEAPPLE (Anenas comosus) FRUIT SKIN}

\begin{abstract}
The pineapple fruit processing industry always produce waste in the form of stems, leaves, fruit skin and tubers. The waste hasnot been optimally used. The fruit, stem, and tuber of pineapple, however, contains bromelain enzyme. Bromelain is classified as protease enzyme sulfhydryl groups that are able to break down the molecular structure of proteins into amino acids. The aim of this study was to isolate bromelain enzyme and determine the protein concentration and ezyme activity from pineapple bark against the gelatine substrate. This research consisted of determining the bromelain concentration and enzyme activity in the optimum condition. The result of bromelain isolation showed that the highest protein concentration was resulted from precipitation with $60 \%$ ammonium sulfate. i.e. $0,039 \%(\mathrm{w} / \mathrm{w})$. The optimum temperature was $65^{\circ} \mathrm{C}$ with the activity of 0,071 units/min and the optimum $\mathrm{pH}$ obtained was 6,5 with the activity of 0,0101 units/min.
\end{abstract}

Keywords: bromelain, gelatin, pineapple fruit skin, ammonium sulphate precipitation

\section{PENDAHULUAN}

Dalam industri pengolahan buah nenas, selalu meninggalkan limbah yang cukup banyak. Umumnya limbah nenas berupa batang, daun, kulit, dan bonggol, yang belum dimanfaatkan secara optimal, bahkan hanya digunakan sebagai pakan ternak.

Menurut Raina (2011), buah nenas mengandung gizi cukup tinggi dan lengkap, seperti protein, lemak, karbohidrat, mineral, dan vitamin. Menurut Whitaker (1991), nenas juga mengandung enzim bromelin, yaitu suatu enzim proteolitik yang dapat mengkatalisis reaksi hidrolisis dari protein. Bagian-bagian tanaman nenas yang telah berhasil diekstraksi enzim bromelinnya adalah daging buah (Utami (2010) dan Gautam et al., (2010)), batang (Gautam et al., (2010)), dan bonggol (Sangi (1989)).

Enzim bromelin memiliki banyak kegunaan. Bagi kesehatan manusia, enzim bromelin dapat mengurangi rasa sakit dan pembengkakan karena luka atau operasi, 
mengurangi radang sendi, menyembuhkan luka bakar, serta meningkatkan fungsi paruparu pada penderita infeksi saluran pernapasan. Selain itu ekstrak nenas yang bersumber dari batang, daging, bonggol, dan kulit yang telah digunakan dalam proses pengempukan daging (Utami, 2010). Informasi tentang kandungan enzim bromelin dalam daging buah nenas, batang, dan bonggol telah banyak dilaporkan. Namun informasi tentang keberadaan enzim bromelin dalam kulit nenas belum pernah dilaporkan. Sehingga, penelitian tentang isolasi dan karakterisasi enzim bromelin yang berasal dari kulit nenas perlu dilakukan.bagian penting dalam kehidupan masyarakat Indonesia.

\section{METODOLOGI PENELITIAN}

\section{Bahan}

Buah nenas diperoleh dari Kabupaten Bolaang Mongondow, kemudian diambil kulitnya. Bahan-bahan kimia yang digunakan berkualitas pro analysi.

\section{Prosedur Analisis}

\section{Pembuatan Ekstrak Kasar Kulit Buah Nenas}

Kulit nenas yang digunakan adalah kulit nenas yang berasal dari buah nenas yang masih mengkal, ditandai dengan warna kulitnya hijau kekuningan. Kulit nenas dicuci dengan aquades, dipotong kecil-kecil dan ditimbang sebanyak 1.500 gram. Selanjutnya dihomogenisasi dengan menggunakan 200 $\mathrm{mL}$ larutan buffer natrium asetat $(\mathrm{pH} 6,5)$, dan disaring. Ekstrak kasar disentrifugasi selama 25 menit pada $3.500 \mathrm{rpm}$, dan disimpan pada $4{ }^{\circ} \mathrm{C}$.

\section{Pengendapan dengan Amonium Sulfat}

Presipitasi ekstrak kasar enzim bromelin dilakukan dengan penambahan amonium sulfat sebanyak $10 \%, 20 \%, 30 \%$, $40 \%, 50 \%$ dan $60 \%$, sambil diaduk menggunakan pengaduk magnet selama 45 menit, dan diinkubasi semalam pada $4{ }^{\circ} \mathrm{C}$. Selanjutnya, disentrifugasi pada $3500 \mathrm{rpm}$ selama 25 menit. Endapan yang dihasilkan dicuci dengan $10 \mathrm{~mL}$ buffer natrium asetat 0,1 M pada kisaran pH 6 - 6,5 (Gautam et al., 2010).

\section{Penentuan Kadar Protein Ekstrak Enzim Bromelin}

Penentuan kadar protein dilakukan dengan menggunakan metode Bradford (Bradford, 1976). Absorbansi diukur pada $\lambda$ $595 \mathrm{~nm}$. Kadar protein ditentukan dengan membandingkan absorbansi ekstrak enzim bromelin dengan kurva standar gelatin.

\section{Penentuan Aktivitas Enzim Bromelin (Pakpakan, 2009) \\ a. Penentuan Temperatur Optimum}

Sebanyak $0,5 \mathrm{~mL}$ gelatin ditambahkan dengan $0,5 \mathrm{~mL}$ buffer asetat dan $0,5 \mathrm{~mL}$ ekstrak enzim bromelin, kemudian diinkubasi selama 10 menit pada berbagai temperatur untuk menentukan temperatur optimum. Temperatur yang digunakan adalah $50{ }^{\circ} \mathrm{C}, 55$ ${ }^{\circ} \mathrm{C}, 60{ }^{\circ} \mathrm{C}, 65{ }^{\circ} \mathrm{C}, 70{ }^{\circ} \mathrm{C}, 75{ }^{\circ} \mathrm{C}$, dan $80{ }^{\circ} \mathrm{C}$. Reaksi dihentikan dengan pemanasan pada air mendidih selama 10 menit. Absorbansi diukur pada $\lambda 595 \mathrm{~nm}$ untk menentukan kadar protein.

\section{b. Penentuan pH optimum}

Sebanyak $0,5 \quad \mathrm{~mL}$ gelatin ditambahkan dengan $0,5 \mathrm{~mL}$ buffer asetat dan $0,5 \mathrm{~mL}$ ekstrak enzim bromelin, kemudian diinkubasi selama 10 menit pada berbagai nilai $\mathrm{pH}$ pada temperatur optimum yang diperoleh. Variasi nilai $\mathrm{pH}$ yang digunakan adalah 5,$0 ; 5,5 ; 6,0 ; 6,5 ; 7,0 ; 7,5 ; 8,0$. Reaksi dihentikan dengan pemanasan pada air mendidih selama 10 menit. Absorbansi diukur pada $\lambda 595 \mathrm{~nm}$.

Satu unit aktivitas enzim didefinisikan sebagai jumlah enzim yang dibutuhkan untuk menghidrolisis substrat gelatin per satuan waktu pada kondisi percobaan.

\section{HASIL DAN PEMBAHASAN}

\section{Kadar Protein Enzim}

Penentuan kadar protein enzim bromelin dilakukan dengan menggunakan metode Bradford dan gelatin sebagai standar. Kadar protein enzim bromelin dalam amonium sulfat tertinggi pada penambahan amonium sulfat $60 \%$, yaitu sebanyak 0,039 $\%$. 


\section{Pengaruh Temperatur Terhadap Aktivitas Enzim Bromelin}

Temperatur sangat erat berhubungan dengan energi aktivitas dan kestabilan enzim. Peningkatan temperatur dapat menyebabkan peningkatan kecepatan reaksi dan secara bersamaan meningkatkan kecepatan inaktivasi enzim (Stauffer, 1989), kenaikan aktivitas pada temperatur 55 sampai dengan $65{ }^{\circ} \mathrm{C}$.

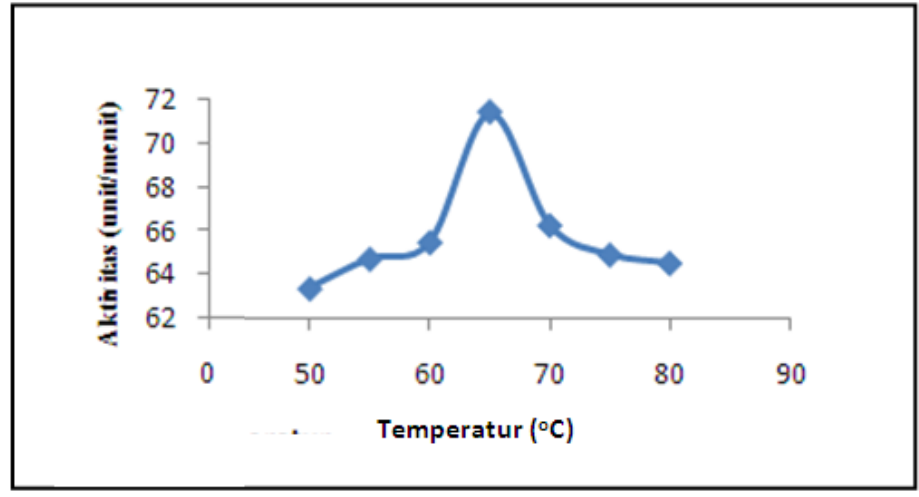

Gambar 1. Pengaruh temperatur terhadap aktivitas enzim bromelin



Gambar 2. Pengaruh $\mathrm{pH}$ terhadap aktivitas enzim bromelin

Gambar 1 menunjukkan temperatur optimum berada pada temperatur $65{ }^{\circ} \mathrm{C}$ dengan aktivitas $0,071 \mathrm{unit} / \mathrm{menit}$, sedangkan pada temperatur 70 sampai dengan $80{ }^{\circ} \mathrm{C}$ terjadi penurunan aktivitas enzim. Harrach $e t$ al., (1998) menemukan temperatur optimum enzim bromelin adalah $65^{\circ} \mathrm{C}$.

Berdasarkan Gambar 1, terlihat bahwa pada temperatur $70{ }^{\circ} \mathrm{C}$ sampai $80{ }^{\circ} \mathrm{C}$ terjadi penurunan aktivitas enzim dibandigkan aktivitas enzim pada $65{ }^{\circ} \mathrm{C}$, hal ini disebabkan karena terjadi denaturasi enzim dengan cepat pada rentang temperatur 70 sampai $80{ }^{\circ} \mathrm{C}$.
Kenaikan temperatur yang lebih tinggi dapat merusak struktur enzim sehingga fungsi kerja enzim dapat berkurang (Pakpahan, 2009).

\section{Pengaruh pH Terhadap Aktivitas Enzim Bromelin}

Aktivitas enzim sangat dipengaruhi oleh $\mathrm{pH}$ medium. $\mathrm{pH}$ saat aktivitas enzim maksimum adalah $\mathrm{pH}$ optimum.

Menurut Nielsen et al., (1999), $\mathrm{pH}$ optimum merupakan $\mathrm{pH}$ saat gugus pemberi dan penerima proton yang berperan penting pada sisi katalitik enzim atau pada sisi pengikat substrat berada dalam tingkat 
ionisasi yang diinginkan, sehingga substrat lebih mudah berinteraksi dengan sisi katalitik enzim. Grafik pengaruh $\mathrm{pH}$ terhadap aktivitas enzim dapat dilihat pada Gambar 2.

Berdasarkan hasil penelitian ini, peningkatan aktivitas enzim mulai teramati dari $\mathrm{pH} 5,0$ sampai $\mathrm{pH}$ optimum 6,5 yaitu sebesar 0,101 unit/menit (Gambar 2). Penurunan aktivitas enzim dari $\mathrm{pH} \quad 7,0$ sampai $\mathrm{pH}$ 8,0 terjadi karena lingkungan di sekitar sisi aktif enzim mengalami kekurangan jumlah proton.

\section{KESIMPULAN}

Berdasarkan penelitian, dapat disimpulkan bahwa kulit nenas memiliki kandungan enzim bromelin, dengan aktivitas optimum diperoleh pada temperatur $65{ }^{\circ} \mathrm{C}$ sebesar 0,071 unit/menit dan pada $\mathrm{pH} 6,5$ sebesar 0,101 unit/menit.

\section{DAFTAR PUSTAKA}

Bradford, M. M. 1976. A rapid and sensitive method for the quantitation of microgram quantities of protein utilizing the principle of protein-dye binding. Anal Biochem 72 , 248-254.

Gautam, S.S., Mishra, S., Dash, V., Amit, K. and Rath, G. 2010. Cooperative study or extraction, purification and estimation of bromelain from stem and fruit of pineapple plant. Thai J. Pharm., Sci. 34, 67-76.

Harrach, T., K. Eckert., H. R. Maurer., I. Machleidt., W. Machleidt., and R. Nuck. 1998. Isolation and characterization of two forms of an acidic bromelain stem proteinase. J. Prot Chem. 17(4): 351-61.

Nielsen, J. E., Beier, L., Otzen., D., Borchert, T. V., Frantzen, H. B., Andersen, K. V., Svendsen, A., (1999), Electrostatics in in the active site of an $\alpha$-amylase, Eur. $J$. Biochem., 246, 816-824

Pakpahan, 2009. Isolasi Bakteri dan Uji Aktivitas Protease Termofilik Dari Sumber Air Panas Sipoholon Tapanuli Utara Sumatera Utara. [Tesis]. Sekolah Pascasarjana Universitas Sumatera Utara. Medan.
Raina, M. H. 2011. Ensiklopedia Tanaman Obat Untuk Kesehatan. Absolut. Yogyakarta

Sangi, M.S. 1989. Pemurnian Enzim Bromelin Dari Bonggol Nenas. Laporan Penelitian Fakultas Peternakan UNSRAT, Manado.

Stauffer, C.E., 1989. Enzyme Assays for Food Scientists. AVI, 30-30.

Utami. 2010. Pengaruh Penambahan Ekstrak Buah Nenas (Anenas comosus L. Merr) Dan Waktu Pemasakan Yang Berbeda Terhadap Kualitas Daging Itik Afkir. Skripsi. Jurusan Peternakan Fakultas Pertanian Universitas Sebelas Maret. Surakarta.

Whitaker, J. R. 1991. Principles of Enzimology For The Food Sciences. Marcel Dekker Inc. New York. 